JEMMA (Jurnal of Economic, Management, and Accounting)

p-ISSN : 2615-1871/ e-ISSN : 2615-5850

http://www.ojs.unanda.ac.id/index.php/jemma/index

\title{
Strategi Manajemen Konflik Dalam Upaya Penyelesaian Konflik Politik: Suatu Tinjauan Teoritis
}

\author{
Mudzakkar NB. ${ }^{1, *}$ \\ ${ }^{1}$ Program Studi Administrasi Negara, Universitas Andi Djemma, Palopo \\ *Correspondent Email:mudzakkar.nb@gmail.com
}

Article History:

Received: 30-08-2020; Received in Revised: 08-09-2020; Accepted: 13-09-2020

DOI: http://dx.doi.org/10.35914/jemma.v3i2.643

\begin{abstract}
Abstrak
Penelitian ini bertujuan untuk mengkaji strategi manajemen konflik dalam upaya penyelesaian konflik politik, suatu tinjauan teoritis. Pendekatan yang digunakan dalam penelitian ini merupakan penelitian kualitatif yang didasarkan pada penelusuran terhadap sejumlah literatul dan paper rujukan yang berkaitan dengan strategi manajemen konflik dalam upaya penyelesaian konflik politik. Hasil kajian menunjukan bahwa konflik dapat terjadi karena adanya pertentangan antara apa yang diharapkan oleh seseorang terhadap dirinya, orang lain, organisasi dengan kenyataan yang terjadi. Ada beberapa penyebab konflik yaitu perbedaan kepribadian, penghambat komunikasi, pertentangan kepentingan, kelangkaan sumber daya, dan gaya administratif yang otokrasi. Ada beberapa strategi yang digunakan dalam menangani konflik termasuk konflik politik antara lain yaitu dengan strategi menghindar, mengakomodasi/ merangkul, kompetisi, kompromi atau negosiasi, dan memecahkan masalah atau kolaborasi dalam menyelesaikan masalah.
\end{abstract}

Kata kunci: manajemen konflik, konflik politik.

\begin{abstract}
This study aims to examine conflict management strategies in efforts to resolve political conflicts, a theoretical review. The approach used in this research is qualitative research based on tracing a number of literatures and reference papers related to conflict management strategies in efforts to resolve political conflicts. The results of the study show that conflict can occur because of a conflict between what a person expects of himself, other people, the organization and the reality that occurs. There are several causes of conflict, namely personality differences, communication barriers, conflicts of interest, scarcity of resources, and an autocratic administrative style. There are several strategies used in dealing with conflicts including political conflicts, including strategies to avoid, accommodate / embrace, competition, compromise or negotiate, and solve problems or collaborate in solving problems.
\end{abstract}

Keywords: conflict management, political conflict. 


\section{Pendahuluan}

Konflik merupakan salah satu esensi yang kerap terjadi dalam kehidupan manusia dengan karakteristik yang cukup beragam. Diantara karateristik manusia tersebut diantaranya, perbedaan jenis kelamin, strata sosial dan ekonomi, sistem hukum, suku, budaya, agama, kepercayaan, aliran politik, bahkan tujuan hidup yang berbeda-beda. Konflik juga dimaknai sebagai benturan dari bermacam-macam paham, keyakinan, perselisihan, tidak adanya kata mufakat, terjadinya pergesekan, bahkan perkelahian, atau perlawanan dengan senjata tajam dan lain sebagainya (Rahim, 2010).

Sepanjang sejarah umat manusia, perbedaan tersebut terkadang selalu menimbulkan konflik. Selama terjadi perbedaan diantara masyarakat, konflik tidak dapat dihindarkan dan selalu akan terjadi. Banyak yang beranggapan bahwa konflik itu selalu menimbulkan dampak negatif, padahal dalam kondisi tertentu konflik justru sangat diperlukan untuk kepentingan perubahan dan pengembangan keperibadian seseorang atau organisasi (Puspita, 2018)

Konflik dapat terjadi antara individu dengan individu, antara kelompok dengan kelompok bahkan antara organisasi dengan organisasi. Apabila dua orang individu atau kelompok masing-masing berpegang pada pandangan yang berbeda maka konflik itu akan terjadi. Oleh karena itu, agar konflik itu bermakna positif diperlukan manajemen yang baik agar mendapatkan hasil yang bermanfaat bagi individu/ kelompok (Handoko, 2001).

Menurut Ross (1993), manajemen konflik merupakan langkah-langkah yang diperlukan para pelaku atau pihak ketiga dalam rangka menyelesaikan perselisihan kearah yang menghasilkan hal positif, kreatif, bermufakat, atau agresif yang saling menguntungkan diantara beberapa pihak. Manajemen konflik juga dapat melibatkan bantuan diri sendiri, kerja sama dalam memecahkan masalah atau pengambilan keputusan oleh pihak ketiga. Suatu pendekatan yang berorientasi pada proses manajemen konflik menunjuk pada pola komunikasi para pelaku dan bagaimana mereka mempengaruhi kepentingan dan penafsiran terhadap konflik.

Secara umum, dua macam konflik yang sering terjadi, yaitu konflik substantif dan konflik emosional. Konflik subtantif berkaitan dengan ketidak sesuaian paham tentang halhal seperti, visi, misi, tujuan, alokasi sumber daya, kebijakan, serta penugasan. Sedangkan konflik emosional timbul karena perasaan marah, jengkel, ketidakpercayaan, ketidaksenangan, takut, dan sikap menentang, maupun bentrokan-bentrokan kepribadian (Minarsih, 2011). Kedua macam konflik ini akan selalu muncul pada setiap organisasi.

Kompleksitas yang seringkali menjadi sumber konflik adalah kompleksitas sumber daya manusia. Ada berbagai kompleksitas yang berkaitan dengan hal ini, yaitu kompleksitas jabatan, kompleksitas tugas, kompleksitas kedudukan dan status, kompleksitas hak dan wewenang dan lain-lain. Kompleksitas ini merupakan sumber potensial untuk timbulnya sebuah konflik (Sitompul, 2018).

Meskipun demikian, konflik tidak perlu dihindari apalagi ditakuti. Konflik hanya butuh penyelesaian yang baik, karena konflik apabila dikelola dengan baik dan benar justru berubah menjadi kekuatan baru yang sangat besar dalam berinovasi serta sangat potensial untuk pengembangan sebuah organisasi. Dalam tataran organisasi atau lembaga, konflik sering terjadi secara tidak simetris. Terjadi hanya satu pihak yang sadar dan memberikan respon 
terhadap konflik tersebut, sementara yang lain tidak, atau satu pihak mempersepsikan adanya pihak lain yang telah atau akan menyerang secara negatif (Nurlimah, 2011).

Konflik politik memang sangat menarik untuk dikaji baik secara konseptual teoritis maupun secara aplikatif berdasarkan pada kasus yang terjadi. Banyak penelitian yang mengkaji konflik politik diantaranya Nurlimah (2011) meneliti Konflik Politik Capres SBY, JK, dan Megawati di Media Massa. Kemudian, Taqwa (2013) mengakaji model analisis konflik politik lokal-pemilukada, suatu perspektif teoritis. Sitompul (2018) meneliti konflik internal partai sebagai salah satu penyebab kompleksitas sistem multipartai di indonesia. Haris (2020), mengkaji konflik politik Antara Angkatan Darat DPRS Dan Sukarno, studi kasus peristiwa 17 Oktober 1952. Selanjutnya, Jumadin \& Wibisono (2020) mengkaji konflik politik antara gubernur dan DPRD DKI Jakarta dalam proses penetapan APBD 2015. Berdasarkan penjelasan tersebut maka penelitian ini bertujuan untuk mengkaji strategi manajemen konflik dalam upaya penyelesaian konflik politik, suatu tinjauan teoritis.

\section{Metodologi}

Pendekatan penelitian ini merupakan penelitian kualitatif yang didasarkan pada penelusuran terhadap sejumlah literatul dan paper rujukan yang berkaitan dengan strategi manajemen konflik dalam upaya penyelesaian konflik politik.

\section{Hasil dan Pembahasan}

\subsection{Teori Konflik}

Konflik merupakan salah satu konsep dasar dalam ilmu sosial yang tidak bisa dihindari dari kehidupan manusia (Rahim, 2010). Sebagai makhluk sosial manusia tidak bisa terlepas dari interaksi dengan orang lain terutama dalam mencapai tujuan hidupnya. Manusia yang secara kodrati dilengkapi dengan nafsu, emosi dalam melakukan hubungan dengan manusia lainnya, sering terjadi pertentangan, kesalahpahaman antara individu dengan individu, antara individu dengan kelompok maupun individu dengan kelompok dan pemerintah. .

Teori konflik adalah teori yang memandang bahwa perubahan sosial terjadi tidak melalui proses penyesuaian nilai-nilai yang membawa perubahan, terjadi karena adanya konflik yang menghasilkan kompromi-kompromi yang berbeda dengan kondisi semula. Konflik terjadi karena adanya hubungan sosial atau komunikasi, apabila kita ingin mengetahui konflik maka harus memahami pola dan perilaku koomunikasi, dan konflik tidak selalu disebabkan oleh komunikasi yang buruk.

Watkins (1974) berpendapat bahwa konflik terjadi bila terdapat beberapa hal. Pertama, konflik bisa terjadi bila sekurang-kurangnya terdapat dua pihak yang secara potensial dan praktis/ operasional dapat saling menghambat secara potensial, artinya mereka memiliki kemampuan untuk menghambat. Hal senada disampaikan oleh Coser (1961) pengertian konflik adalah perjuangan antar individu atau kelompok untuk memenangkan sesuatu tujuan yang sama-sama ingin mereka capai. Dimana kekalahan dan kehancuran dipihak lawan, merupakan tujuan utama yang ingin mereka capai. Dengan demikian konflik ibarat sebuah permainan (Suparlan, 1999).

Fenomena konflik telah diteliti oleh berbagai para ilmuan seperti ekonom, sejarawan, novelis, filsuf, ilmuwan politik, sosiolog, psikolog, teolog, dan ilmuan lainnya yang fokus mengkaji tentang dinamika konflik. Timbulnya konflik adalah adanya pihak tertentu yang terlibat dalam konflik bukan untuk mencapai suatu tujuan melainkan untuk menikmati konflik itu sendiri. Maka inti dari konflik itu adalah menyangkut masalah perbedaan 
dan pertentangan antar individu yang akhirnya merebak menjadi konflik sosial (Rahim, 2010).

Pada dasarnya konflik politik disebabkan oleh dua hal yaitu konflik yang disebabkan oleh kemajemukan horizontal dan konflik politik yang disebabkan oleh kemajemukan vertikal. Yang dimaksud dengan kemajemukan horizontal adalah struktur masyarakat majemuk secara kultural, seperti suku bangsa, daerah, agama, dan ras. Kemajemukan kultural dapat menimbulkan gesekan-gesekan yang berakibat timbulnya konflik karena pada dasarnya setiap kultur akan mempertahankan identitas dan karakteristik budaya. Apalagi pada era sekarang dimana sistim informasi sudah begitu maju sehingga proses masuk dan keluarnya informasi sangat mudah dan hal ini bisa mengancam eksistensi suatu kultur. Dalam kehidupan masyarakat untuk menghindari terjadinya konflik politik yang diakibatkan kemajemukan horizontal perlu adanya konsensus nilai-nilai yang menjadi pegangan bersama. dengan demikian konflik politik yang disebabkan oleh benturan budaya dapat dihindari.

Konflik juga bisa disebabkan oleh faktor kemajemukan horizontal sosial karena masingmasing kelompok yang berdasarkan pada profesi, pekerjaan dan tempat tinggal tersebut memiliki kebutuhan dan kepentingan yang berbeda bahkan saling bertentangan. Kemajemukan vertikal adalah struktur masyarakat yang berlawanan menurut pemilikan kekayaan, pengetahuan dan kekuasaan, konflik dapat ditimbulkan oleh kemajemukan vertikal, karena adanya perbedaan bahkan pertentangan kepentingan kelompok mayoritas yang tidak memiliki atau sedikit memiliki kekayaan, pengetahuan dan kekuasaan dengan kelompok minoritas yang mendominasi kekayaan, kekuasaan, dan pengetahuan (Didiharyono \& Qur'ani, 2019). Jadi kekayaan, kekuasaan, dan pengetahuan bisa menjadi penyebab utama timbulnya konflik. Akan tetapi kenyataan menunjukkan perbedaan kepentingan karena kemajemukan horizontal dan kemajemukan vertikal tidak dengan sendirinya menimbulkan konflik. Hal ini disebabkan kenyataan adanya masyarakat yang menerima perbedaanperbedaan tersebut.

Perbedaan perbedaan akan menimbulkan konflik jika individu atau kelompok memperebutkan sumber-sumber yang sama seperti kekuasaan, kesempatan dan sebagainya. Konflik terjadi manakala terdapat benturan kepentingan. Dalam rumusan lain dapat dikemukakan konflik bisa terjadi apabila ada pihak yang merasa diperlakukan tidak adil atau adanya pihak yang berperilaku menyentuh "titik kemarahan" pihak lain. dengan kata lain perbedaan kepentingan karena kemajemukan horizontal dan verikal merupakan situasi dan kondisi yang harus ada dalam konflik, tetapi perbedaan kepentingan itu bukan kondisi yang memadai untuk menimbulkan konflik. Tujuan konflik untuk mendapatkan sumber-sumber kekuasaan merupakan untuk dapat hidup secara layak dan terhormat dalam masyarakat. Tujuan konflik jiga digunakan untuk mempertahankan kekuasaan adalah dalam memelihara sumber-sumber yang menjadi miliknya dan berupaya mempertahankan dari usaha-usaha pihak lain untuk merebut dan mengurangi sumber-sumber tersebut (Surbakti, 2010).

Menurut Rahim (2010), menjelaskan fungsi dari terjadinya suatu konflik yaitu sebagai berikut:

- Konflik dapat merangsang inovasi, kreativitas, dan perubahan yang terjadi.

- Proses pengambilan keputusan organisasi dapat ditingkatkan.

- Solusi alternatif untuk suatu masalah dapat ditemukan.

- Konflik dapat mengarah pada solusi sinergis untuk masalah umum.

- Kinerja individu dan kelompok dapat ditingkatkan.

- Individu dan kelompok mungkin terpaksa mencari pendekatan baru untuk menyelesaikan masalah yang dihadapi.

- Individu dan kelompok mungkin diminta untuk mengartikulasikan dan menjelaskan posisi mereka berkaitan dengan konflik yang terjadi. 


\subsection{Penyebab Konflik}

Setelah menyadari bahwa konflik adalah konsep sosial yang penting dalam ilmu sosial khususnya ilmu pemerintah. Konflik merupakan salah satunya fenomena utama dalam suatu organisasi (Rahim, 2010). Dalam suatu organisasi konflik kerap terjadi antara manajer dan bawahan, tenaga kerja dan manajemen; kelompok kerja, dan antara organisasi dengan lingkungan eksternal dan lain sebagainya. Jimoh-Kadiri (2012) menyuraikan beberapa penyebab konflik dalam suatu organisasi yaitu sebagai berikut

1. Perbedaan Kepribadian.

Perbedaan kepribadian ini menjadi salah satu faktor penyebab terjadinya konflik. Terkadang, individu yang sikap dan perilakunya tidak setuju terkadang ditugaskan untuk bekerja sama. Jika mereka mengabaikan kebutuhan satu sama lain, konflik dapat terjadi. Selain itu, perbedaan persepsi individu juga bisa menyebabkan ketidaksepakatan ketika staf manajemen tidak bijaksana dalam memperkenalkan perubahan dan proses, bisa terjadi gesekan.

2. Penghambat Komunikasi.

Konflik muncul sebagai akibat adanya hambatan dalam proses komunikasi. Komunikasi sebagai transfer makna, yaitu dari sumber ke penerima. Itu adalah pemindahan makna dari satu orang ke lain. Ketidakjelasan dalam komunikasi menciptakan masalah yang serius dan kesalahpahaman yang bisa menimbulkan konflik. Pimpinan dalam sebuah organisasi menyelesaikan konflik dengan cara mengubah budaya organisasi, dengan mendatangkan pekerja dari perusahaan lain, merestrukturisasi organisasi, dan lain sebagainya.

c. Pertentangan Kepentingan.

Kepentingan yang bertentangan mungkin menyebabkan terjadi perbedaan tujuan di antara anggota-anggota dalam suatu organisasi. Perilaku yang tidak dewasa atau pertentangan kepentingan di banyak pihak, staf manajemen, atau karyawan juga dapat menyebabkan konflik.

\section{d. Kelangkaan Sumber Daya.}

Sumber daya organisasi tidak selalu cukup. Manusia, uang, bahan, dan waktu untuk memenuhi semua kebutuhan mungkin terbatas sehingga, menimbulkan konflik. Selanjutnya, ketika seseorang mencari sesuatu secara mutual sumber daya yang diinginkan oleh orang lain, yang kekurangan pasokan, yang sedang berkembang atau persaingan yang dihasilkan juga dapat menimbulkan konflik.

e. Gaya Administratif yang Otokrasi.

Gaya administrasi yang dianut oleh seorang administrator cenderung menjadi sumber konflik jika memiliki gaya otokrasi (berkuasa sendiri). Kapan janji temu dan promosi dilakukan oleh manajemen tanpa konsultasi dan kerjasama dari pihak kepala unit, juga menyebabkan terjadinya konflik.

\subsection{Manajemen Konflik}

Istilah manajemen konflik berasal dari kata manajemen dan konflik. Manajemen memiliki arti seni melaksanakan dan mengatur. Mary Parker Follet dalam Handoko (2001), mendefinisikan manajemen sebagai seni menyelesaikan pekerjaan melalui orang lain. Manajemen berarti proses mengatur melalui orang lain. Sedangkan, konflik adalah proses pertentangan yang diekspresikan diantara dua pihak atau lebih yang saling tergantung 
mengenai objek konflik, menggunakan pola perilaku dan interaksi konflik yang menghasilkan keluaran konflik. Dengan demikian, manajemen Konflik adalah proses pihak yang terlibat konflik atau pihak ketiga menyusun strategi konflik dan menerapkannya untuk mengendalikan konflik agar menghasilkan resolusi yang diinginkan (Gunawan \& Rante, 2011). Hal ini selaras dengan pendapat Ogonor (2004), bahwa manajemen konflik adalah sebuah strategi digunakan untuk mengurangi frekuensi yang merusak (destruktif) dengan memperkuat penghambat tindakan konflik dan mengendalikan peristiwa penyebab terjadinya konflik.

Igbinoba (2011) melihat manajemen konflik sebagai istilah yang mengacu pada sebuah sengketa yang belum terselesaikan. Manajemen konflik juga dikenal sebagai metode yang digunakan orang-orang dalam menangani perselisihan. Tidak hanya itu, Ogonor (2004: 250) memandang bahwa manajemen konflik bertujuan untuk membatasi dan menghindari kekerasan antara dua pihak. Sehingga, dapat mempengaruhi setiap tindakan yang diambil sebelum atau setelah konflik terjadi dengan tujuan utama dapat mengurangi efek dari konflik tersebut dan untuk memastikan kedua pihak dapat hidup dalam harmoni yang damai dan bertingkah laku secara tertib sesuai dengan aturan yang ada (Tekleab dkk, 2009).

Menurut Handoko (2001), terdapat lima langkah dalam menyelesaikan konflik dan mengatasi kesulitan dari konflik tersebut, yaitu Pertama, Pengenalan. Kesenjangan antara keadaan yang ada atau yang teridentifikasi dan bagaimana keadaan yang seharusnya. Satusatunya yang menjadi perangkap adalah kesalahan dalam mendeteksi atau tidak mempedulikan masalah atau menganggap ada masalah padahal sebenarnya tidak ada. Kedua, diagnosis. Inilah langkah yang terpenting untuk memeriksa dengan baik penyebab terjadinya konflik. Metode yang benar dan telah diuji mengenai siapa, apa, mengapa, dimana, dan bagaimana berhasil dengan sempurna, serta memusatkan perhatian pada masalah utama dan bukan pada hal-hal sepele. Ketiga, menyepakati suatu solusi. Tahapan ini harus dilakukan dengan menyumpulkan masukan mengenai jalan keluar yang memungkinkan dari orangorang yang terlibat di dalamnya dan memeriksa penyelesaian yang tidak dapat diterapkan atau tidak praktis dengan solusi yang terbaik. Keempat, pelaksanaan. Tahapan ini berkaitan dengan pelaksanaan sesuai dengan solusi yang dirumuskan berdasarkan keuntungan dan kerugian dalam proses pelaksanaanya. Dan kelima, evaluasi. Tahapan penyelesaian itu sendiri dapat melahirkan serangkaian masalah baru. Jika penyelesaiannya tampak tidak berhasil, kembalilah ke langkah-langkah sebelumnya sebagai bahan evaluasi untuk perbaikan sesuai dengan tahapan-tahapan sebelumnya (Ramsbotham dkk, 2011).

\subsection{Penyelesaian Konflik}

Sementara itu Mangkunegara, (2009), merumuskan ada beberapa strategi yang harus dilakukan oleh pemimpin dan rakyat dalam menangani dan menyelesaikan konflik. Strategi tersebut antara lain yaitu Pertama, menghindar. Menghindari konflik dapat dilakukan jika isu atau masalah yang memicu konflik tidak terlalu penting atau jika potensi konfrontasinya tidak seimbang dengan akibat yang akan ditimbulkannya. Menghindar merupakan strategi yang memungkinkan pihak-pihak yang berkonfrontasi untuk menenangkan diri. Pemimpin yang terlibat didalam konflik dapat menepiskan isu agar kedua pihak yang berkonflik mengambil waktu untuk memikirkan hal ini dan menentukan tanggal untuk melakukan diskusi.

Kedua, mengakomodasi. Memberi kesempatan pada orang lain untuk mengatur strategi pemecahan masalah, khususnya apabila isu tersebut penting bagi orang lain. Hal ini memungkinkan timbulnya kerjasama dengan memberi kesempatan pada mereka untuk membuat keputusan. Perawat yang menjadi bagian dalam konflik dapat mengakomodasikan pihak lain dengan menempatkan kebutuhan pihak lain di tempat yang pertama. Ketiga, kompetisi. Gunakan metode ini jika anda percaya bahwa anda memiliki lebih banyak informasi dan keahlian yang lebih dibanding yang lainnya atau ketika anda tidak ingin 
mengkompromikan nilai-nilai anda. Metode ini mungkin bisa memicu konflik tetapi bisa jadi merupakan metode yang penting untuk alasan- alasan keamanan. Keempat, kompromi atau negosiasi. Masing-masing memberikan dan menawarkan sesuatu pada waktu yang bersamaan, saling memberi dan menerima, serta meminimalkan kekurangan semua pihak yang dapat menguntungkan semua pihak. Dan kelima, memecahkan masalah atau kolaborasi. Pemecahan sama-sama menang dimana individu yang terlibat mempunyai tujuan kerja yang sama. Perlu adanya satu komitmen dari semua pihak yang terlibat untuk saling mendukung dan saling memperhatikan satu sama lainnya (Muspawi, 2014).

Sedangkan Gibson dalam Gunawan \& Rante (2011) menyumbangkan konsep bagi langkah penyelesaian konflik yang efektif antara lain yaitu pertama, menjabarkan kepentingan. Teknik penyelesaian konflik ini ditempuh melalui, (a) dengan memudahkan pencarian kepentingan yang sama dan tidak berkonflik dari kedua kelompok; (b) dengan membicarakan kepentingan setiap kelompok kepada yang lain tanpa menyorot secara tidak pantas kelompok yang lain untuk memaksakan kepentingan dengan dasar kepentingan tertentu. Kedua, membangun hubungan kerja yang baik. Teknik penyelesaian konflik ini ditempuh melalui, (a) memberi kesempatan kepada kelompok untuk mengatasi perbedaanperbedaannya dalam perdebatan yang hangat; (b) memelihara jenis hubungan yang diinginkan oleh kelompok tapi sesuai; (c) mempermudah kelompok untuk mengatasi bersama-sama bila konflik timbul lagi. Ketiga, memberikan pilihan yang baik. Teknik penyelesaian konflik ini ditempuh melalui, (a) memacu kelompok untuk sumbang saran beberapa pilihan sebelum mengevaluasi mereka dan memilih di antara mereka; (b) mendorong/memberi semangat kepada kelompok untuk mencari jalan keluar untuk menciptakan nilai-nilai untuk perolehan bersama.

Keempat, dilihat sebagai keabsahan. Teknik penyelesaian konflik ini ditempuh melalui (a) dengan tidak dipandang oleh kelompok sebagai pengganggu; \{b) dengan menanamkan pada kelompok rasa bahwa penyelesaian yang dibuat akan adil dan memadai. Kelima, pengenalan alternatif prosedural suatu pihak. Teknik penyelesaian konflik ini ditempuh dengan membolehkan kedua pihak untuk mengembangkan penilaian mereka sendiri yang realistis dan alternatif pokok pihak lain. Keenam, memperbaiki komunikasi. Teknik penyelesaian konflik ini ditempuh melalui, (a) memperbanyak pertanyaan dan pengujian dari yang menjadi dasar perkiraan; (b) mempermudah pengertian dan diskusi dari pandangan pengikut; (c) membentuk komunikasi antar kelompok dua arah yang efektif. Ketujuh, mengarahkan kekomitmen yang bijaksana. Teknik penyelesaian konflik ini ditempuh melalui (a) memberi kesempatan kelompok untuk merancang kebijaksanaan yang realistis, operasional dan cendrung terlaksana; (b) menempatkan pihak-pihak dengan sumber yang efektif untuk acara di kejadian yang mereka gagal untuk mencapai persetujuan akhir atau kejadian yang tidak terlaksana (Gunawan \& Rante, 2011).

\section{Kesimpulan}

Konflik dapat dipahami sebagai suatu kondisi yang menyebabkan pertentangan antara apa yang diharapkan oleh seseorang terhadap dirinya, orang lain, organisasi dengan kenyataan yang terjadi. Ada beberapa penyebab konflik yaitu perbedaan kepribadian, penghambat komunikasi, pertentangan kepentingan, kelangkaan sumber daya, dan gaya administratif yang otokrasi. Ada beberapa strategi yang digunakan dalam menangani konflik termasuk konflik politik antara lain yaitu, dengan strategi menghindar, mengakomodasi/ 
merangkul, kompetisi, kompromi atau negosiasi, dan memecahkan masalah atau kolaborasi. Adapun saran dalam pengembangan penelitian selanjutnya yaitu agar bisa melakukan penelitian manajemen konflik dengan contoh kasus konflik politik yang terjadi di tengah masyarakat.

\section{Daftar Pustaka}

Coser, L. A. (1961). The Termination of Conflict. Journal of Conflict Resolution, 5(4), 347353.

Didiharyono, D., \& Qur'ani, B. (2019). Increasing Community Knowledge Through the Literacy Movement. To Maega: Jurnal Pengabdian Masyarakat, 2(1), 17-24.

Gunawan, K., \& Rante, Y. (2011). Manajemen konflik atasi dampak masyarakat multikultural di Indonesia. Jurnal Mitra Ekonomi dan Manajemen Bisnis, 2(2), 212224.

Irwan, I., \& Haryono, D. (2015). Pengendalian Kualitas Statistik (Pendekatan Teoritis dan Aplikatif). Bandung: Alfabeta.

Handoko, T. H. (2001). Manajemen personalia dan sumber daya manusia, edisi kedua. Yogyakarta: BPFE.

Haris, F. A. (2020). Konflik Politik Antara Angkatan Darat DPRS Dan Sukarno: Studi Kasus Peristiwa 17 Oktober 1952: Political Conflict Between the Dprs Army and Sukarno: Case Study of the October 17, 1952. Uniqbu Journal of Social Sciences, 1(1), 38-44.

Igbinoba, G.O. (2011). Peace Studies and Conflict Resolution. Published by Otoghagua Ent. Nigeria (BR) Benin City.

Jimoh-Kadiri, S.O. (2012). Management Theory and Practice. Benin City: Rudel Publishers; 7 (96-III).

Jumadin, Z., \& Wibisono, Y. (2020). Konflik Politik Antara Gubernur Dan DPRD DKI Jakarta Dalam Proses Penetapan APBD 2015. Jurnal Sosial dan Humaniora, 4(8).

Mangkunegara, A.A. (2009). Manajemen Sumber Daya manusia Perusahaan. Bandung: Rosda Karya

Mannuhung, S., Tenrigau, A. M., \& Didiharyono, D. (2018). Manajemen Pengelolaan Masjid dan remaja Masjid di Kota Palopo. To Maega: Jurnal Pengabdian Masyarakat, 1(1), 14-21.

Minarsih, M. M. (2011). Konflik Kerja, Stres Kerja dan Cara Mengatasinya. Dinamika Sains, 9(20).

Muspawi, M. (2014). Manajemen Konflik (Upaya Penyelesaian Konflik dalam Organisasi). Jurnal Penelitian Universitas Jambi Seri Humaniora 16(2), 41-46

Nurlimah, N. (2011). Konflik Politik Capres SBY, JK, dan Megawati di Media Massa. MIMBAR: Jurnal Sosial dan Pembangunan, 27(1), 1-10.

Ogonor, B.O. (2004). Conflict Management and Resolution in Organization and Administration of Education. Perspectives and Practices Festa Printing Press LTD; 11(249-257).

Puspita, W. (2018). Manajemen Konflik: Suatu Pendekatan Psikologi, Komunikasi, dan Pendidikan. Deepublish.

Rahim, M. A. (2010). Managing Conflict In Organizations. New York: Taylor \& Francis. 
Ramsbotham, O., Miall, H., \& Woodhouse, T. (2011). Contemporary Conflict Resolution. Polity, Bradford University.

Ross, Joel E. (1993). Total Quality Management: Text, Cases and Readings, London: Kogan Page Limited.

Sitompul, C. (2018). Konflik Internal Partai Sebagai Salah Satu Penyebab Kompleksitas Sistem Multipartai di Indonesia. Jurnal Legislasi Indonesia, 5(1), 102-129.

Suparlan, P. (1999). Konflik Sosial dan Alternatif Pemecahannya. Antropologi Indonesia. XXIII, 69-105.

Surbakti, R. (2010). Memahami Ilmu Politik. Jakarta (ID): PT Gramedia Widiasarana Indonesia.

Taqwa, R. (2013). Model Analisis Konflik Politik Lokal-Pemilukada Suatu Perspektif Teoritis. Paper Universitas Sriwijaya

Tekleab, A. G., Quigley, N. R., \& Tesluk, P. E. (2009). A longitudinal Study of Team Conflict, Conflict Management, Cohesion, and Team Effectiveness. Group \& Organization Management, 34(2), 170-205.

Watkins, C. E. (1974). An Analytic Model of Conflict. Communications Monographs, 4l(1), 1-5. 